\title{
DIMENSI SYARIAH COMPLIANCE PADA OPERASIONAL BANK SYARIAH
}

\author{
Miti Yarmunida \\ IAIN Bengkulu \\ Email: yarmunidamiti@gmail.com
}

\begin{abstract}
Label Bank Syariah is not only a name, the consequences of the name impact on all aspects of its operations. Sharia Bank Operations must / must comply with the principles of sharia (Sharia Compliance). Broadly speaking there are seven dimensions of shariah compliance in the operations of Islamic Banks as follows: 1) does not contain elements of usury, 2) avoid bai 'al-inah, 3) does not contain gharar, 4) does not contain maisir, 5) Business run based on (7) Managing zakat, infaq and shadaqah in accordance with syariah Keywords: Sharia Compliance, Bank Syaria'h
\end{abstract}

Abstrak: Label Bank Syariah tidak hanya sebuah nama, konsekuensi nama tersebut berimbas pada seluruh aspek operasionalnya. Operasional Bank Syariah harus/wajib patuh pada prinsip-prinsip syariah (Syariah Compliance). Secara garis besar ada tujuh dimensi syariah compliance dalam operasional Bank syariah sebagai berikut 1) tidak mengandung unsur riba, 2) terhindar dari bai' al-inah, 3) tidak mengandung gharar, 4) tidak mengandung maisir, 5) Bisnis yang dijalankan berbasis pada keuntungan yang halal, 6) Menjalankan amanah yang dipercayakan nasabah pada bank, 7) Mengelola zakat, infaq dan shadaqah sesuai dengan syariah

Kata Kunci: Syariah Compliance

\section{A. PENDAHULUAN}

Bank syariah di Indonesia mulai beroperasi pada tahun 1996 dengan diresmikannya Bank Muamalat Indonesia oleh Presiden Soeharto. Berdirinya Bank Muamalat Syariah sebagai manifestasi keinginan masyarakat muslim dunia terutama Indonesia bahwa Mereka menginginkan bertransaksi dengan lembaga perbankan yang tidak menggunakan sistem bunga pada produknya. Perbankan syariah adalah satu sistem yang dibangun dengan semangat alternatif, sehingga harus berbeda dari perbankan yang telah ada. Perbedaan sistem tidak sekedar pemakaian istilah, tetapi juga perlakuan terhadap jaminan rasa aman terhadap nasabah. Oleh karena itu, pencantuman -label syariah, pada hakekatnya mengandung konsekuensi yang cukup berat, sehingga mekanisme pengawasannya perlu diperketat agar menjaga amanah dan kepercayaan nasabah terjaga dengan baik.

Mengingat latar belakang pendirian Bank Muamalat Indonesia tersebut, Sudah Selayaknya jika operasionalnya harus patuh pada prinsip-prinsip syariah dalam bermuamalah. Bank syariah yang ada di Indonesia Sudah Cukup dewasa $( \pm 26$ tahun), perkembangannya juga sudah luar biasa dan regulasi terus dibenahi untuk menjadikan bank syariah tersebut benarbenar syar'i. Dengan demikian industri perbankan syariah sejatinya dijalankan berdasarkan prinsip dan sistem syariah. Oleh karena itu kesesuaian operasi dan praktik bank syariah dengan syariah Islam merupakan piranti mendasar dalam perbankan syariah, namun dalam 
prakteknya masih banyak penyimpangan dari prinsip-prinsip Syariah. Tulisan ini akan membahas tentang dimensi kepatuhan syariah pada operasional bank syariah.

\section{B. PEMBAHASAN}

Berdasarkan Peraturan Bank Indonesia Nomor 13/2/PBI/2011 tentang Pelaksanaan Fungsi Kepatuhan Bank Umum, maka yang dimaksud kepatuhan adalah nilai, perilaku, dan tindakan yang mendukung terciptanya kepatuhan terhadap ketentuan Bank Indonesia dan peraturan perundang-undangan yang berlaku, termasuk prinsip syariah bagi bank umum syariah dan unit usaha syariah. ${ }^{1}$ Menurut Arifin, makna kepatuhan syariah (syariah compliance) dalam bank syariah adalah -penerapan prinsip-prinsip Islam, syariah dan tradisinya dalam transaksi keuangan dan perbankan serta bisnis lain yang terkait ${ }^{2}$ Selain itu Ansori juga mengemukakan bahwa syariah compliance adalah salah satu indikator pengungkapan islami untuk menjamin kepatuhan bank Islam terhadap prinsip syariah.

Hal ini berarti syaria compliance sebagai bentuk pertanggungjawaban pihak bank dalam pengungkapan

${ }^{1}$ B. Indonesia, Peraturan Bank Indonesia tentang Pelaksanaan Fungsi Kepatuhan Bank Umum, (Jakarta: ttp, tth),

${ }^{2}$ Zainal Arifin, dasar-dasar Manajemen Bank syariah, (Tanggerang: Aztera Publisher, 2009), h.2 kepatuhan bank terhadap prinsip syariah. ${ }^{3}$

$$
\text { Kepatuhan syariah }
$$

(Syariah compliance) merupakan manifestasi pemenuhan seluruh prinsip syariah dalam lembaga yang memiliki wujud karakteristik, integritas dan kredibilitas di bank syariah. Dimana budaya kepatuhan tersebut adalah nilai, perilaku dan tindakan yang mendukung terciptanya kepatuhan bank syariah terhadap seluruh ketentuan Bank Indonesia. (Indonesia, Peraturan Bank Indonesia Tentang Pelaksanaan Fungsi Keptauhan Bank Umum, 2011) Sedangkan menurut Adrian Sutedi, makna kepatuhan syariah secara operasional adalah kepatuhan kepada Fatwa Dewan Syariah Nasional (DSN) karena Fatwa DSN merupakan perwujudan prinsip dan aturan syariah yang harus ditaati dalam perbankan syariah $^{\mathbf{4}}$ Menyangkut tata-cara bermuamalat secara Islam ${ }^{5}$ Prinsip utama bank syariah tercermin dalam produkproduk yang dihasilkannya bebas bunga dengan menggunakan prinsip bagi hasil.

Pemahaman yang dapat diambil dari beberapa definisi tersebut $\mathrm{d}$ atas bahwa kepatuhan syariah (syariah compliance)

\footnotetext{
${ }^{3}$ Ansori, Pengungkapan Syariah Compliance dan Kepatuhan Bank Syariah terhadap prinsip syariah, Jurnal Dinamika, Vol.3 No. 2 Maret 2001

${ }^{4}$ Andrian Sutedi, Perbankan Syariah, Tinjauan dan Beberapa Segi Hukum, (Jakarta: Ghalia Indonesia, 2009), h. 145

${ }^{5}$ Muhammad Syafii Antonio, Bank Syariah Bagi Banker dan Praktisi Keuangan, (Jakarta: Tazkia Institute, 2001), h.14
} 
merupakan pelaksanaan secara

keseluruhan terhadap nilai-nilai syariah di lembaga keuangan syariah (dalam hal ini perbankan syariah) yang menjadikan fatwa DSN MUI dan peraturan Bank Indonesia (BI) sebagai alat ukur pemenuhan prinsip syariah, baik dalam produk, transaksi, dan operasional di bank syariah.

Bank Indonesia sebagai pemegang kebijakan perbankan di Indonesia telah menjadikan fatwa DSN sebagai hukum positif bagi perbankan syariah. Artinya, fatwa DSN menjadi peraturan Bank Indonesia yang mengatur aspek syariah bagi perbankan syariah. Tujuan formalisasi fatwa DSN menjadi peraturan Bank Indonesia dalam aspek kepatuhan syariah adalah untuk menciptakan keseragaman norma-norma dalam aspek syariah untuk keseluruhan produk bank. ${ }^{6}$

Kepatuhan syariah tersebut secara konsisten dijadikan sebagai kerangka kerja bagi sistem dan keuangan bank syariah dalam alokasi sumber daya, manajemen, produksi, aktivitas pasar modal, dan distribusi kekayaan. ${ }^{7}$ Kepatuhan terhadap prinsip syariah ini berimbas kepada semua hal dalam industri

${ }^{6}$ Andrian Sutedi, Perbankan Syariah, Tinjauan dan Beberapa Segi Hukum, h. 145. lihat juga; Siti maria Wardayati, Implikasi Syariah Governance terhadap Reputasi dan Kepercayaan Bank Syariah, dalam jurnal Walisongo Vol. 19. No. 1 Mei 2011. h.3

${ }^{7}$ Andrian Sutedi, Perbankan Syariah, Tinjauan dan Beberapa Segi Hukum, h. 145 perbankan syariah, terutama dengan produk dan transaksinya. Kepatuhan syariah dalam operasional bank syariah tidak hanya meliputi produk saja, akan tetapi juga meliputi sistem, teknik, dan identitas perusahaan. Oleh karena itu, budaya perusahaan, yang meliputi pakaian, dekorasi, dan image perusahaan juga merupakan salah satu aspek kepatuhan syariah dalam bank syariah yang bertujuan untuk menciptakan suatu moralitas dan spiritual kolektif, yang apabila digabungkan dengan produksi barang dan jasa, maka akan menopang kemajuan dan pertumbuhan jalan hidup yang islami. ${ }^{8}$

Bank syariah telah memenuhi kepatuhan pada prinsip-prinsip syariah (syariah complience) apabila dalam semua transaksi dan kegiatan usahanya tidak mengandung unsur riba, gharar dan maisir, menjalankan bisnis yang berbasis pada keuntungan yang halal, menjalankan amanah yang dipercayakan nasabah pada bank dan mengelola zakat, infaq dan shadaqah dengan amanah. ${ }^{9}$

Ketentuan Syariah Compliance. Sebagai salah satu jenis lembaga keuangan syariah, maka perbankan

\footnotetext{
${ }^{8}$ Andrian Sutedi, Perbankan Syariah, Tinjauan dan Beberapa Segi Hukum, h. 145

${ }^{9}$ Siti maria Wardayati, Implikasi Syariah Governance terhadap Reputasi dan Kepercayaan Bank Syariah, dalam jurnal Walisongo Vol. 19. No. 1 Mei 2011. h.8
} 
syariah dalam operasionalnya harus taat pada prinsip-prinsip syariah (syariah copliance), setidaknya secara garis besar ada 7 (tujuh) dimensi syariah compliance dalam operasional perbankan syariah adalah

\section{Tidak Ada Riba Dalam Transaksi}

\section{Bank}

Riba secara bahasa artinya adalah tambahan. ${ }^{10}$ Makna lain dari riba secara bahasa adalah tumbuh dan membesar. $^{11} \quad$ Al- Jurjani mengemukakan pengertian riba adalah kelebihan atau tambahan pembayaran tanpa adanya ganti atau imbalan yang disyaratkan bagi salah satu dari dua pihak yang membuat akad atau transaksi. $^{12}$ Sedangkan menurut AlAini, riba adalah penambahan atas harta pokok tanpa adanya akad atau transaksi jual beli yang riil. 13 Pengertian riba yang lain dikemukakan oleh Qal'eaji dan Qunaibi, menurut mereka riba adalah tambahan yang dipersyaratkan dalam suatu akad tanpa adanya ganti yang dibenarkan oleh

${ }^{10}$ Muhammad Rawwas Qal'aji dan Hamid Qunaibi, Mu'jam Lughat al-Fuqaha, Cet.II, (Beirut: Dar al-Nafa'is, 1988), h.218

${ }^{11}$ Muhammad Rawwas Qal'aji dan Hamid Qunaibi, M u'jam Lughat al-Fuqaha, h.218

${ }^{12} \mathrm{Ali}$ bin Muhammad al-Syarif al-Jurjani, Kitab al-Ta' rifat, (Beirut: Maktabah Libnan, 1990), h.4

${ }^{13}$ Badar al-Din Abi Muhammad al-Aini, U.a.Q, Syarh Sahih al-Bukhari, (Beirut: Dar al-Fikr, tth), syara. $^{14}$

Menurut Oni Sahroni, riba terbagi dua yaitu: Riba qardh dan riba buyu'. Riba buyu' tersebut mencakup riba fadhl dan riba nasi'ah. ${ }^{15}$ Berdasarkan al-Quran surat al-Baqarah ayat 275:

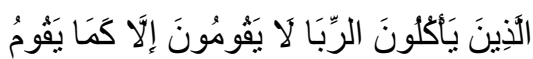

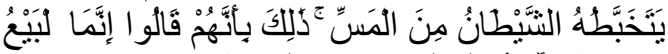

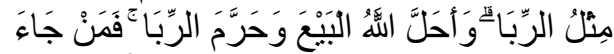

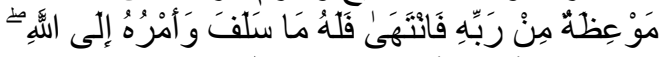

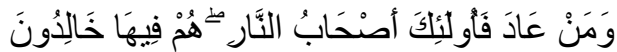

"Orang-orang yang Makan (mengambil) riba ${ }^{16}$ tidak dapat berdiri melainkan seperti berdirinya orang yang kemasukan syaitan lantaran (tekanan) penyakit gila. ${ }^{17}$ Keadaan mereka yang demikian itu, adalah disebabkan mereka berkata (berpendapat), Sesungguhnya jual beli itu sama dengan riba, Padahal Allah telah menghalalkan jual beli dan mengharamkan riba. orang-orang yang telah sampai kepadanya larangan dari Tuhannya, lalu terus berhenti (dari mengambil riba), Maka baginya apa yang telah diambilnya dahulu ${ }^{18}$ (sebelum datang larangan); dan urusannya (terserah) kepada Allah. orang yang kembali (mengambil riba),

${ }^{14}$ Muhammad Rawwas Qal'aji dan Hamid Qunaibi, M u'jam Lughat al-Fuqaha, h. 199

${ }^{15}$ Adi Warman Karim dan Oni Sahroni, Riba, Gharar dan kaidah-kaidah Ekonomi syariah, (Jakarta: Raja Grafindo Persada, 2015), h. 1

${ }^{16}$ Riba itu ada dua macam: nasiah dan fadhl. Riba nasiah ialah pembayaran lebih yang disyaratkan oleh orang yang meminjamkan. Riba fadhl ialah penukaran suatu barang dengan barang yang sejenis, tetapi lebih banyak jumlahnya karena orang yang menukarkan mensyaratkan demikian, seperti penukaran emas dengan emas, padi dengan padi, dan sebagainya. Riba yang dimaksud dalam ayat ini Riba nasiah yang berlipat ganda yang umum terjadi dalam masyarakat Arab zaman jahiliyah.

${ }^{17}$ Maksudnya: orang yang mengambil Riba tidak tenteram jiwanya seperti orang kemasukan syaitan.

${ }^{18}$ Riba yang sudah diambil (dipungut) sebelum turun ayat ini, boleh tidak dikembalikan. 
Maka orang itu adalah penghunipenghuni neraka; mereka kekal di dalamnya."

Al-Baqarah 278:

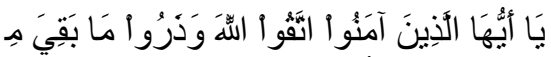

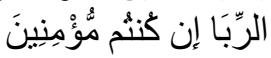

"Hai orang-orang yang beriman, bertakwalah kepada Allah dan tinggalkan sisa Riba (yang belum dipungut) jika kamu orang-orang yang beriman."

Ali Imron ayat 130:

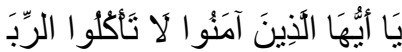

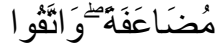

"Hai orang-orang yang beriman, janganlah kamu memakan Riba dengan berlipat ganda ${ }^{19}$ dan bertakwalah kamu kepada Allah supaya kamu mendapat keberuntungan."

Lafaz riba yang disebutkan dalam 3 ayat al-quran di atas adalah riba qard atau riba jahiliyah atau riba nasiah.

Dalil dari Hadits yang artinya:

"ubadah Bin shamit meriwayatkan bahwa Rasulullah bersabda:(penukaran) antara emas dengan emas perak dengan perak gandum dengan gandum, syair dengan syair, dengan,, garam dengan garam itu harus sama dan dibayar kontan. Jika berbeda penukaran barang diatas maka

\footnotetext{
${ }^{19}$ Yang dimaksud Riba di sini ialah Riba nasi'ah. menurut sebagian besar ulama bahwa Riba nasi'ah itu selamanya haram, walaupun tidak berlipat ganda. Riba itu ada dua macam: nasiah dan fadhl. Riba nasiah ialah pembayaran lebih yang disyaratkan oleh orang yang meminjamkan. Riba fadhl ialah penukaran suatu barang dengan barang yang sejenis, tetapi lebih banyak jumlahnya karena orang yang menukarkan mensyaratkan demikian, seperti penukaran emas dengan emas, padi dengan padi, dan sebagainya. Riba yang dimaksud dalam ayat ini Riba nasiah yang berlipat ganda yang umum terjadi dalam masyarakat Arab zaman jahiliyah.
}

jual lah barang tersebut sesuka hati kalian dengan syarat dibayar kontan". (HR Ahmad)

"Dia berkata Saya pernah menjual unta di Baqi' saya menjualnya dengan beberapa Dinar dan saya mengambil beberapa dirham (sebagai pengganti Dirham). kemudian saya datang menemui Nabi Shallallahu Alaihi Wasallam di rumah Hafsah, saya berkata: wahai Rasulullah Saya ingin bertanya Sesungguhnya saya menjual unta di Baqi'saya menjualnya dengan Dinar dan mengambil dirham. Beliau bersabda: tidak mengapa engkau mengambilnya dengan harga pada hari itu selama kalian berdua belum berpisah dan ada sesuatu Diantara Kalian (taqabbud)". hadis riwayat Nasa'i, Abu Dawud, Ahmad, dan Hakim).

Lafaz riba yang disebutkan dalam hadits di atas adalah riba buyu' yang termasuk didalamnya riba fadhl dan riba nasiah. Dalam Sirah, riba qardh juga sering disebut riba jahiliyah, atau dalam tafsir sering disebut riba nasiah. jadi riba jahiliyah, riba nasiah dan riba qardh itu maknanya sama. ${ }^{20}$

Dengan demikian, yang dimaksud dengan riba adalah penambahan pendapatan secara tidak sah antara lain dalam transaksi pertukaran barang sejenis yang tidak sama kualitas, kuantitas, dan waktu penyerahan atau dalam transaksi pinjam-meminjam yang mempersyaratkan penerima fasilitas

${ }^{20}$ Adi Warman Karim dan Oni Sahroni, Riba, Gharar dan kaidah-kaidah Ekonomi syariah, h. 3 
mengembalikan dana yang diterima melebihi pokok pinjaman karena berjalannya waktu. Riba terjadi di bank syariah apabila penentuan tambahan pinjaman karena ada penundaan waktu pelunasan.

\section{Terhindar dari bai' al-'inah}

Menurut Oni Sahroni bai' al-'inah dapat didefinisikan dari aspek pembeli dan aspek penjual. Dari aspek pembeli bai'al-inah adalah seseorang membeli barang secara tidak tunai dengan kesepakatan akan menjualnya kembali kepada penjual pertama dengan harga lebih kecil secara tunai. Sedangkan dari aspek penjual bai'al-inah adalah seseorang menjual barang secara tunai dengan kesepakatan akan membelinya kembali dari pembeli yang sama dengan harga yang lebih kecil secara tidak tunai. $^{21} \quad$ Menurut Sebagian ulama bai'al-inah adalah seseorang membeli barang secara tidak tunai dengan kesepakatan akan menjualnya kembali kepada penjual pertama dengan harga lebih kecil secara tunai. Dengan demikian, maka dapat disebutkan karakteristik bai' al-inah adalah orang yang membutuhkan uang itu yang membeli barang secara tidak tunai dan menjual barang secara tunai, ada dua akad dalam bai' al-inah, tunai dan tidak

${ }^{21}$ Adi Warman Karim dan Oni Sahroni, Riba, Gharar dan kaidah-kaidah Ekonomi syariah, h. 50 tunai, dalam akad pertama penjual (kredit/muqtarid) menjual dengan tunai mendapatkan bunga atas pinjaman, dalam abad kedua, pembeli/debitur/muqtarid itu membeli dengan tidak tunai (harga lebih rendah) iya rugi tapi memenuhi kebutuhan akan uang.

Menurut para ulama sesungguhnya motivasi pembeli dalam transaksi bai' al-inah bukan barang, tetapi memenuhi kebutuhannya akan uang. oleh karena itu calon penjual menawarkannya untuk membeli barang yang dimilikinya dengan harga tidak tunai dan kemudian dibelinya kembali dengan tunai. Sehingga pembeli mendapatkan dana tunai sebagian digunakan untuk memenuhi angsuran pertama terhadap penjual dan sisanya untuk memenuhi kebutuhannya, sedangkan penjual mengambil selisih harga beli dan jual. ${ }^{22}$

\section{Terhindar dari gharar}

Menurut ahli fiqih gharar adalah sifat dalam muamalah yang menyebabkan sebagian rukunnya tidak pasti. Secara operasional negara dapat diartikan kedua belah pihak dalam transaksi tidak memiliki kepastian terhadap barang yang menjadi objek transaksi baik terkait kualitas kuantitas harga dan waktu penyerahan barang

22 Adi Warman Karim dan Oni Sahroni, Riba, Gharar dan kaidah-kaidah Ekonomi syariah, h. 52 
sehingga pihak kedua dirugikan. ini terjadi bila mengubah sesuatu yang pasti menjadi tidak pasti contohnya gharar dalam kualitas seperti penjual yang menjual anak sapi yang masih dalam kandungan; Suara dalam kuantitas seperti jual-beli ijon; Gharar dalam harga seperti murabahah rumah 1 tahun dengan margin $20 \%$ atau murabahah 2 tahun dengan margin 40\%; Gharar dalam waktu penyerahan seperti menjual barang yang hilang. ${ }^{23}$

Dasar hukum pelarangan gharar dalam syariat Islam sebagaimana Hadits Rasulullah Shallallahu Alaihi Wasallam" naha Rasulullah Shallallahu Alaihi Wasallam an bai' gharar" Imam nawawi menjelaskan bahwa hadis ini menjelaskan prinsip penting dalam berbisnis yang mengatur masalah-masalah yang tidak terbatas menurutnya di antara contoh gharar Menjual buah Jika buahnya belum matang itu berarti gharar karena ada kemungkinan matang atau tidak. Pemikiran imam nawawi di atas sangat tepat di antara praktik-praktik bisnis terlarang dalam fiqih muamalah gharar dan riba adalah praktik bisnis yang memiliki ruang lingkup yang cakupannya luas. Dalam praktiknya

${ }^{23}$ Adi Warman Karim dan Oni Sahroni, Riba, Gharar dan kaidah-kaidah Ekonomi syariah, h. 78 hampir setiap praktik bisnis terlarang itu terdapat unsur gharar di dalamnya. ${ }^{24}$

Pembeli bertransaksi untuk mendapatkan barang yang tanpa cacat dan sesuai keinginan begitu pula penjual bertransaksi untuk mendapatkan keuntungan. Oleh karena itu kondisi yang merugikan salah satu atau seluruh pelaku akan dan sangat mungkin menimbulkan perselisihan dan permusuhan. Sesungguhnya setiap transaksi dalam Islam harus didasarkan pada prinsip kedaulatan antara kedua belah pihak mereka harus mempunyai informasi yang sama sehingga tidak ada pihak yang merasa dicurangi karena ada sesuatu yang tidak diketahui. dalam keempat bentuk transaksi di mana keadaan sama-sama rela yang dicapai bersifat sementara yaitu sementara keadaannya masih tidak jelas bagi kedua belah pihak, maka jika di kemudian hari ketidakjelasan nya telah jelas salah satu pihak akan merasa terdzolimi walaupun pada awalnya tidak demikian. $^{25}$ Inilah tujuan dilarangnya gharar agar tidak ada pihak-pihak yang akan dirugikan. Karena tidak mendapatkan haknya dan agar tidak terjadi perselisihan dan permusuhan diantara mereka. Gharar atau disebut

\footnotetext{
${ }^{24}$ Adi Warman Karim dan Oni Sahroni, Riba, Gharar dan kaidah-kaidah Ekonomi syariah, h. 79

${ }^{25}$ Adi Warman Karim dan Oni Sahroni, Riba,
} Gharar dan kaidah-kaidah Ekonomi syariah, h. 80 
juga taghrir adalah situasi di mana terjadi incomplete information karena adanya uncertainty to both parties (ketidakpastian dari kedua belah pihak yang bertransaksi). Di sini, baik pihak A maupun pihak B sama-sama tidak memiliki tidak kepastian mengenai suatu yang ditransaksikan (uncertain to both parties). Gharar terjadi bila sesuatu yang sifatnya pasti (certain) menjadi tidak pasti (uncertain). ${ }^{26}$

\section{Tidak ada maisir dalam transaksi bank}

Maisir dalam bahasa Arab adalah qimar yang berarti judi ${ }^{27}$ maisir adalah suatu transaksi yang digantungkan kepada suatu keadaan yang tidak pasti dan bersifat untunguntungan. Secara sederhana, maisir atau perjudian adalah suatu permainan yang menjadikan salah satu pihak menanggung beban pihak lain akibat permainan tersebut. Setiap permainan atau pertandingan harus menghindari terjadinya zero sum game, yaitu keadaan yang menjadikan salah satu pihak harus menanggung beban pihak yang lain. ${ }^{28}$

\footnotetext{
${ }^{26}$ Muhammad Rawwas Qal'aji dan Hamid Qunaibi, M u'jam Lughat al-Fuqaha, h. 470

${ }^{27}$ Muhammad Rawwas Qal'aji dan Hamid Qunaibi, Mu'jam Lughat al-Fuqaha, h. 470; Adi Warman Karim, Bank Islam Analisis Fiqh dan Keuangan, (Jakarta: Raja Grafindo Persada, 2007), h. 32

${ }^{28}$ Adi Warman Karim, Bank Islam Analisis Fiqh dan Keuangan, h. 43
}

Menurut Adi Warman Karim dan

Oni Sahroni suatu transaksi atau permainan dikatakan maisir apabila mengandung unsur-unsur yaitu taruhan dan mengadu nasib sehingga pelaku bisa menang dan bisa kalah, seluruh pelaku maisir mempertaruhkan hartanya. begitu juga dengan pelaku judi, mereka mempertaruhkan hartanya tanpa imbalan, pemenang mengambil hak orang lain yang kalah. Setiap pelaku tidak memberi manfaat kepada lawannya, orang yang menang mengambil sesuatu dan yang kalah tidak mengambil imbalannya, pelaku berniat mencari uang dengan mengadu nasib, tidak ada target lain. Hal ini untuk membedakan dengan permainan yang tidak mencari sarana mencari uang. Seperti bermain bola di lapangan yang disewa, dengan perjanjian siapa yang kalah, maka dia yang menanggung biaya sewa lapangan tersebut. $^{29}$

Berdasarkan empat unsur di atas, maka setiap transaksi atau permainan yang mengandung keempat unsur tersebut maka termasuk transaksi haram karena mengandung maisir.

Keharaman maisir berdasarkan QS. Al-Maidah ayat 90 :

\footnotetext{
${ }^{29}$ Adi Warman Karim dan Oni Sahroni, Riba Gharar dan Kaidah-kaidah Ekonomi Syariah, Jakarta: PT. Raja Grafindo Persada, 2015. h. 193
} 


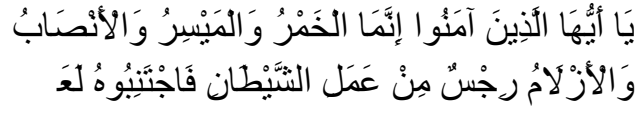

"Hai orang-orang yang beriman, Sesungguhnya (meminum) khamar, berjudi, (berkorban untuk) berhala, mengundi nasib dengan panah, ${ }^{30}$ adalah Termasuk perbuatan syaitan. Maka jauhilah perbuatan-perbuatan itu agar kamu mendapat keberuntungan."

Dalam dunia perbankan transakasi yang sangat berpeluang mengandung maisir yaitu pada jual beli valuta asing dan perdagangan di pasar modal. Sebagai pedoman operasional pada jual beli mata uang sudah di ataur dalam fatwa DSN-MUI Nomor 28/DSNMUI/III/ 2002, dan tentang pedoman umum penerapan prinsip syariah di pasar modal terdapat dalam fatwa DSN-MUI no.40/DSN-MUI/X/2003 dan Fatwa DSN-MUI Nomor 80/DSNMUI/III/2011.

${ }^{30} \mathrm{Al}$ Azlaam artinya: anak panah yang belum pakai bulu. orang Arab Jahiliyah menggunakan anak panah yang belum pakai bulu untuk menentukan Apakah mereka akan melakukan suatu perbuatan atau tidak. Caranya Ialah: mereka ambil tiga buah anak panah yang belum pakai bulu. setelah ditulis masingmasing Yaitu dengan: lakukanlah, jangan lakukan, sedang yang ketiga tidak ditulis apa-apa, diletakkan dalam sebuah tempat dan disimpan dalam Ka'bah. bila mereka hendak melakukan sesuatu Maka mereka meminta supaya juru kunci ka'bah mengambil sebuah anak panah itu. Terserahlah nanti Apakah mereka akan melakukan atau tidak melakukan sesuatu, sesuai dengan tulisan anak panah yang diambil itu. kalau yang terambil anak panah yang tidak ada tulisannya, Maka undian diulang sekali lagi

\section{Bank menjalankan bisnis berbasis} pada keuntungan yang halal

Halal secara bahasa artinya adalah diperbolehkan oleh syara ${ }^{\text {ee }}$ atau kebalikan dari haram (Qal'aji tt). Sebagai lembaga keuangan yang melekat kepadanya nama syariah sudah semestinya dalam operasionalnya mengikuti ketentuan-ketentuan syariah atau prinsip-prinsip syariah. Prinsip tersebut adalah prinsip hukum Islam dalam kegiatan perbankan berdasarkan fatwa yang dikeluarkan oleh Dewan Syariah Nasional Majelis Ulama Indonesia (DSN-MUI) Bank syariah harus menerapkan prinsip-prinsip tersebut sehingga dapat menjalankan bisnis berbasis pada keuntungan yang halal.

Pihak yang mengawasi penerapan prinsip tersebut adalah Dewan Pengawas Syariah (DPS). DPS berperan dalam mengawal dan memastikan bank syariah menjalankan bisnis pada keuntungan yang halal. Apabila terdapat suatu transaksi yang diragukan kehalalannya, maka manajemen bank syariah meminta pendapat kepada DPS. DPS kemudian melakukan rapat untuk membahas dan memutuskan status hukum transaksi tersebut. Dalam hal ini bank syariah wajib mengikuti pendapat yang 
dikeluarkan oleh DPS.

\section{Bank menjalankan amanah yang}

\section{dipercayakan oleh nasabah}

Amanah adalah sesuatu yang harus dijaga karena adanya transaksi perjanjian ataupun tidak adanya transaksi perjanjian. Konsep wadiah mendapat pengakuan dan legalitas syara'. di antaranya firman Allah surah al-baqarah ayat 283 :

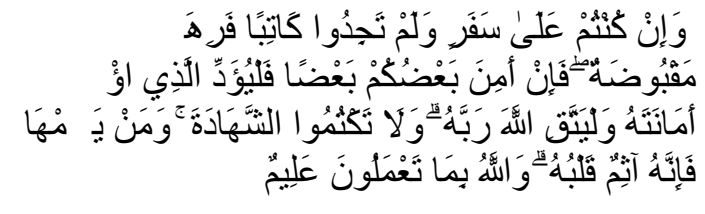

" Jika kamu dalam perjalanan (dan bermu'amalah tidak secara tunai) sedang kamu tidak memperoleh seorang penulis, Maka hendaklah ada barang tanggungan yang dipegang[180] (oleh yang berpiutang). akan tetapi jika sebagian kamu mempercayai sebagian yang lain, Maka hendaklah yang dipercayai itu menunaikan amanatnya (hutangnya) dan hendaklah ia bertakwa kepada Allah Tuhannya; dan janganlah kamu (para saksi) Menyembunyikan persaksian. dan Barangsiapa yang menyembunyikannya, Maka Sesungguhnya ia adalah orang yang berdosa hatinya; dan Allah Maha mengetahui apa yang kamu kerjakan.

Dan QS. Annisa ayat 58:

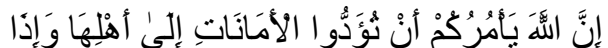

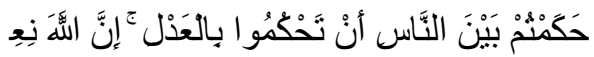

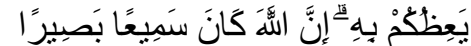

\footnotetext{
"Sesungguhnya Allah menyuruh kamu menyampaikan amanat kepada yang berhak menerimanya, dan (menyuruh kamu) apabila menetapkan hukum di antara manusia supaya kamu menetapkan dengan adil. Sesungguhnya Allah memberi pengajaran yang sebaikbaiknya kepadamu. Sesungguhnya Allah
}

adalah Maha mendengar lagi Maha melihat."

Dalam hadis juga dijelaskan sebagaimana diriwayatkan Dawud dan Tirmidzi:" tunaikanlah amanah itu kepada orang yang memberi amanah kepadamu dan janganlah kamu menghianati orang yang memberi amanah kepadamu dan jangan kamu menghianati orang yang menghianatimu".

Ketika kontrak wadiah telah disepakati oleh kedua belah pihak, pemilik aset memiliki hak penjagaan aset yang dititipkan, sedangkan penerima titipan berkewajiban untuk menjaganya. Apabila ada dua orang menitipkan asetnya kepada seseorang, kemudian datang salah satu dari mereka dan meminta aset mereka kembali, maka aset itu tidak boleh dikembalikan sehingga pihak kedua datang menemui mereka.

Amanah karena adanya transaki perjanjian, contohnya akad wadiah dan ijarah. Amanah yang tidak ada transaksi perjanjian, contohnya barang temuan yang disimpan oleh orang yang menemukannya. $^{31}$ Bank syariah harus amanah dalam menjalankan bisnis dan mengelola dana nasabah yang dipercayakan kepadanya.

Bank mengelola zakat, infaq dan shadaqah sesuai ketentuan syar'i. Dari segi bahasa kata zakat merupakan kata

${ }^{31}$ Muhammad Rawwas Qal'aji dan Hamid Qunaibi, M u'jam Lughat al-Fuqaha, h. 470 
dasar dari zaka yang berarti berkah, tumbuh, bersih, dan baik. Dalam lisanul Arab arti dasar dari kata zakat ditinjau dari sudut bahasa adalah suci, tumbuh, berkah dan terpuji. Secara istilah fikih, zakat adalah "sejumlah harta tertentu yang diwajibkan Allah diserahkan kepada orang-orang yang berhak" di samping berarti " mengeluarkan jumlah tertentu itu sendiri". Jumlah yang dikeluarkan dari kekayaan itu dinamakan zakatkarena yang dikeluarkan itu menambah banyak, membuat lebih berarti, dan melindungi kekayaan itu dari kebinasaan. ${ }^{32}$ Adapun, shadaqah adalah suatu pemberian dengan mengharap balasan atau pahala dari Allah swt.

Di antara perbedaan bank syariah dengan bank konvensional adalah adanya kewajibanyang melekat pada Bank Syariah untuk mengelola zakat. Bentuk kewajiban tersebut adalah dengan membayar zakat, menghimpun zakat, mencatatnya dalam sistem administrasi yang baik dan mendistribusikannya. Selain mengelola zakat, bank syariah pun wajib mengelola infak dan sedekah. Ini merupakan fungsi dan peran yang melekat pada bank syariah untuk memobilisasi dana-dana sosial.

\footnotetext{
${ }^{32}$ Yusuf Qardawi, Hukum Zakat, (Jakarta: Lentera Antar Nusa, 2002), h. 34
}

Jaminan kepatuhan syariah (syariah compliance assurance) atas keseluruhan aktivitas bank syariah merupakan hal yang sangat penting bagi nasabah dan masyarakat. Beberapa ketentuan yang dapat digunakan sebagai ukuran secara kualitatif untuk menilai ketaatan syariah di dalam lembaga keuangan syariah, antara lain sebagai berikut. ${ }^{33}$ akad atau kontrak yang digunakan untuk pengumpulan dan penyaluran dana sesuai dengan prinsip-prinsip syariah dan aturan syariah yang berlaku. Dengan demikian akadnya harus terpenuhi rukun dan syaratnya, dan tidak melanggar prinsip-prinsip yang diatur dalam akad, dana zakat dihitung dan dibayar serta dikelola sesuai dengan aturan dan prinsip-prinsip syariah. Salah satu perbedaan yang signifikan antara Bank Konvensional dengan Bank Syariah adalah pada pengelolaan dana Ziswaf dan disalurkan dalam produk Qardh al-Hasan, seluruh transaksi dan aktivitas ekonomi dilaporkan secara wajar sesuai dengan standar akuntansi syariah yang berlaku. Laporan ini diatur sebagai bentuk pengawasan kepada Bank Syariah dalam hal kepatuhannya pada prinsip syariah, lingkungan kerja dan corporate culture sesuai dengan syariah. Termasuk lingkungan kerja

${ }^{33}$ Andrian Sutedi, Perbankan Syariah, Tinjauan dan Beberapa Segi Hukum, h. 146 
yang syar'i dalam hal tata cara berpakaian yang menutup aurat, beretika islami baik terhadap rekan kerja terutama kepada nasabah, bisnis usaha yang dibiayai tidak bertentangan dengan syariah. Dalam menyalurkan dana melalui pembiayaan jenis apapun Bank Syariah harus memperifikasi dan dan melakukan survey terlebih dahulu tentang kebenaran informasi yang diberikan oleh calon nasabah termasuk kehalalan bisnis yang akan dibiayai. Bisnis yang akan dibiayai tidak boleh bisnis yang dilarang oleh Islam seperti bisnis prostitusi, bisnis minuman yang mengandung zat yang memabukkan, bisnis peternakan babi, bisnis penipuan, dana lain-lain.

Terdapat Dewan Pengawas Syariah (DPS) sebagai pengarah syariah atas keseluruhan aktivitas operasional bank syariah. Dewan Pengawas Syariah merupakan dewan pakar ekonomi Islam dan ulama yang menguasai bidang fiqh mu'amalah (Islamic commercial jurisprudence) yang berdiri sendiri dan bertugas mengamati dan mengawasi operasional lembaga keuangan syariah dan produk-produknya agar sesuai dengan ketentuan-ketentuan syariat Islam, yaitu dengan mengawasi secara teliti bagaimana bentuk-bentuk perikatan/akad yang dilaksanakan oleh lembaga keuangan syariah Peran dan fungsi. ${ }^{34}$ Dengan demikian, Dewan Pengawas Syariah seyogyanya tidak hanya mengoreksi laporan yang diberikan oleh Bank Syariah.

Sumber dana berasal dari sumber yang sah dan halal menurut syariah.35 Meskipun ini sulit diditeksi oleh Bank Syariah akan tetapi pihak Bank syariah wajib selektif dalam menerima dana yang akan mereka kelola baik dalam bentuk investasi kepemilikan Bank Syariah maupun sebagai nasabah pemasok dana.

Ketentuan-ketentuan tersebut merupakan prinsip-prinsip umum yang menjadi acuan bagi manajemen bank syariah dalam mengoperasikan bank syariah, termasuk dalam produk gadai. Kepatuhan syariah dalam operasional bank syariah dinilai berdasarkan ketentuan, yaitu apakah operasional bank telah dilaksanakan sesuai dengan ketentuan umum kepatuhan syariah tersebut. Sehingga keberadaan DPS dalam struktur bank syariah merupakan aplikasi dari tuntutan pemenuhan prinsip ini.

\section{Pengawasan Kepatuhan Bank syariah}

Terdapat dua konsep yang

\footnotetext{
${ }^{34}$ Muhammad Jatim, Tugas dan Fungsi DPS pada Perbankan syariah, (Jakarta: ttp, 2018)

${ }^{35}$ Andrian Sutedi, Perbankan Syariah,
} Tinjauan dan Beberapa Segi Hukum, h. 145 
mendasari pelaksanaan pengawasan syariah secara internal di bank syariah dalam konteks pemenuhan akuntabilitas secara horizontal dan transendental. Pertama, konsep syariah review harus dilakukan oleh DPS untuk melakukan pengawasan terhadap kepatuhan syariah. Kedua, konsep internal sharia riview bank syariah sebagai salah satu fungsi internal audit dalam bank syariah untuk menilai kesesuaian operasi dan transaksi dengan prinsip-prinsip syariah yang telah ditentukan. 36

Penjelasan pengawasan internal syariah dalam bank syariah tersebut memberikan kesimpulan bahwa pengawasan internal syariah merupakan suatu mekanisme atau sistem pengendalian secara internal untuk menilai dan menguji seluruh aktivitas dan operasi serta produk bank syariah terhadap kepatuhan atas prinsip-prinsip dan aturan syariah yang telah ditetapkan. Sistem pengawasan internal syariah ditentukan oleh dua fungsi pengawasan dalam bank syariah yaitu DPS melalui sharia riview, dan internal audit melalui internal syariah review. Oleh karena itu, untuk memastikan bahwa operasional bank

\footnotetext{
${ }^{36}$ Ardhaningsih, Syariah Compliance Akad Murabahah Pada Bri Syariah Kc. Surabaya Gubeg. Skripsi Universitas Erlangga Surabaya, 2012, h.43-44
}

syariah telah memenuhi prinsip-prinsip syariah, maka bank syariah harus memiliki institusi internal independen yang khusus dalam pengawasan kepatuhan syariah, yaitu DPS. DPS merupakan badan independen yang ditempatkan oleh DSN pada bank syariah yang anggotanya terdiri dari para ahli bidang Fiqh Muamalah dan memiliki pengetahuan umum dalam bidang perbankan. Pengawasan eksternal secara berkala dilakukan oleh BI dan tim audit syariah yang datang ke bank syariah tiga bulan sekali. (Ardhaningsih, 2012). Pengawasan bank syariah memiliki keunikan dengan adanya aspek syariah yang harus diawasi di luar kegiatan operasional. Pengawasan dalam bidang keuangan dan operasional dilakukan oleh BI sebagai otoritas perbankan, sedangkan pengawasan aspek kepatuhan syariah dilakukan oleh DPS.

Bank Indonesia menetapkan beberapa hal yang perlu diperhatikan di dalam pengendalian risiko kepatuhan adalah terciptanya efektifitas dan independensi fungsi audit, Quality assurance unit (apabila ada), dan satuan kerja Manajemen Risiko. Akurasi kelengkapan dan integritas laporan serta sistem informasi manajemen dan keberadaan sistem 
pemantauan terhadap irregulirities

yang mampu mengidentifikasi dan mengukur peningkatan frekuensi dan jumlah eksposure risiko.

\section{KESIMPULAN}

Pembahasan di atas memberikan pemahaman bahwa konsekuensi nama Bank Syariah berimbas pada seluruh aspek operasionalnya. Operasional Bank Syariah harus/wajib patuh pada prinsip-prinsip syariah (Syariah Compliance). Secara garis besar ada tujuh dimensi syariah compliance dalam operasional Bank syariah sebagai berikut: 1) tidak mengandung unsur riba, 2) terhindar dari bai' al-inah, 3) tidak mengandung gharar, 4) tidak mengandung maisir, 5) Bisnis yang dijalankan berbasis pada keuntungan yang halal, 6) Menjalankan amanah yang dipercayakan nasabah pada bank, 7) Mengelola zakat, infaq dan shadaqah sesuai dengan syariah. DAFTAR PUSTAKA

\section{DAFTAR PUSTAKA}

al-Jurjani, A. b.-S. (1990). Kitab al-Ta'rifat. Beirut: Maktabah Libanon.

Ansori. (Vol. 3 Nomor. 2 tahun 2001). Pengungkapan Syariah Compliance dan Kepatuhan Bank Syariah terhadap Prinsip Syariah. Jurnal Dinamika Akuntansi , Antonio, M. S. (2001). Bank Syariah bagi Banker dan Praktisi Keuangan. Jakarta: Tazkia Institut.

Ardhaningsih, G. S. (2012). Syariah Compliance Akad Murabahah pada BRI Syriah KC. Surabaya Gubeg. Skripis Universitas Erlangga Surabaya , 43-44.

Arifin, Z. (2009). Dasar-dasar Manajemen Bank Syariah. Tanggerang: Aztera Publisher.

Badr al-Din Abi Muhammad al-Aini, U. a.-Q. (tt). Syarh Sahih al-Bukhari. Beirut: Dar al-Fikr.

Peraturan bank Indonesia Nomor 13/2/PBI/2011. A B. Indonesia. Jakarta.

Indonesia, B. (2011). Peraturan Bank Indonesia Tentang Pelkasanaan Fungsi Keptauhan Bank Umum. Jakarta.

Jatim, M. (Jumat / Juli / 2018). Tugas dan Fungsi DPS pada Perbankan Syariah. Jakarta.

Karim, A. W. (2007). A Bank Islam Analisis Fiqh dan Keuangan (p. 32). Jakarta: Raja Grafindo.

Qardawi, Y. (2002). Pengertian Zakat. A Y. Qardawi, Hukum Zakat (p. 34). Jakarta: Lentera Antar Nusa.

Qunaibi, M. R. (1988). Mu'jam Lighat alFuqaha. Beirut: Dar al-Nafais.

Sahroni, O. (2015). Bai' al-Inah. A O. Sahroni, Riba, Gharar dan Kaidakaidah Ekonomi Islam (p. 51). Jakarta: Raja Grafindo. 
Sutedi, A. (2009). Perbankan Syariah, Tinjauan dan Beberapa Segi Hukum. Jakarta: Ghalia Indonesia.

Waryati, S. M. (2011). Implikasi Syariah Govermance Terhadap Reputasi dan Kepercayaan Bank Syariah. Walisongo, 3. 